\title{
PREPARATION AND PROPERTIES OF GOLD(III)DITHIOCARBAMATO COMPLEXES
}

\author{
BY
}

\author{
J. G. M. VAN DER LINDEN \\ (Department of Inorganic Chemistry, University of Nijmegen, Driehuizerweg 200, \\ Nijmegen, The Netherlands).
}

The preparations of a series of compounds containing the bis $(N, N$-di-alkyldithiocarbamato)gold(III)-ion of formula $\left[\mathrm{Au}\left(\mathrm{R}_{2} \mathrm{dtc}\right)_{2}\right]^{+} X^{-}$, with $\mathrm{R}=\mathrm{H}$, Me, Et, $n-\mathrm{Pr}, n-\mathrm{Bu}$ and $\mathrm{Ph}$, and with $X^{-}=\mathrm{Br}^{-}, \mathrm{ClO}_{4}^{-}, \mathrm{PF}_{6}{ }^{-}, \mathrm{AgBr}_{2}{ }^{-}, \mathrm{AuBr}_{2}{ }^{-}, \mathrm{B}\left(\mathrm{Ph}_{4}{ }^{-}\right.$, $\mathrm{Au}\left(\mathrm{S}_{2} \mathrm{C}_{6} \mathrm{H}_{3} \mathrm{CH}_{3}\right)_{2}{ }^{-}$, and $\mathrm{Au}\left(\mathrm{S}_{2} \mathrm{C}_{2}(\mathrm{CN})_{2}\right)_{2}{ }^{-}$are reported.

The $\mathrm{C}-\mathrm{N}$ stretching frequencies are measured in the crystalline state as well as in chloroform solutions. These data show that some negative ions have a distinct effect on the $\mathrm{C}-\mathrm{N}$ stretching frequency in the solid state, but this effect is absent in chloroform solutions. Since X-ray studies have shown that these anions are situated near the nitrogen atom of the cation their effect on the $\mathrm{C}-\mathrm{N}$ frequencies is due to a polarisation of the $\mathrm{C}-\mathrm{N}$ bond.

Electric conductivity measurements reveal these complexes to be $1: 1$ electrolytes in nitrobenzene solutions. From the measurements in this solvent several limiting ionic conductances are determined.

\section{Introduction}

The recently reported complexes, all with the same cation, $\left[\mathrm{Au}\left(R_{\mathbf{2}^{-}}\right.\right.$ dtc) $\left.)_{2}\right]^{+} X^{-1}$ where $X^{-}=\mathrm{Br}^{-2}, \mathrm{AuBr}_{2}{ }^{-3}$ and $\mathrm{AuBr}_{4}{ }^{-2}$ for $R=n$-butyl, show differences in the $\mathrm{C}-\mathrm{N}$ stretching frequencies in the infrared spectra. This effect was considered to be due to an inductive effect on the nitrogen by the anions situated close beside it between the butyl chains ${ }^{2}$.

Further investigations have been made to study this effect in the series $\mathrm{Au}\left(R_{2} \mathrm{dtc}\right)_{2} X$, with $X=\mathrm{ClO}_{4}{ }^{-}, \mathrm{PF}_{6}{ }^{-}, \mathrm{B}(\mathrm{Ph})_{4}{ }^{-}, \mathrm{Au}(\mathrm{mnt})_{2}{ }^{-}$and $\mathrm{Au}(\mathrm{tdt})_{2}{ }^{-}$ for $R=n$-butyl and with $X=\mathrm{Br}^{-}$and $\mathrm{AuBr}_{2}{ }^{-}$for $R=\mathrm{H}$, methyl, ethyl, $n$-propyl, and phenyl. The infrared spectra have been recorded in the crystalline state as well as in chloroform solutions. To demonstrate that this interaction exists only in the solid state and to show the ionic character of these complexes, conductivity measurements in nitrobenzene were carried out.

1 In this paper the following abbreviations are used: $R_{2} \mathrm{dtc}=N, N$-di-alkyldithiocarbamate ion $=\mathrm{S}_{2} \mathrm{CNR}_{2}{ }^{-}$, mnt $=$maleonitriledithiolate ion $=\mathrm{S}_{2} \mathrm{C}_{2}(\mathrm{CN})_{2}{ }^{2-}$, tdt $=$ toluene3,4-dithiolate ion $=\mathrm{S}_{2} \mathrm{C}_{6} \mathrm{H}_{3} \mathrm{CH}_{3}{ }^{2-}$.

${ }^{2}$ P. T. Beurskens, J. A. Cras and J. G. M. van der Linden, Inorg. Chem. 9, 475 (1970).

${ }^{3}$ P. T. Beurskens, H.J. A. Blaauw, J. A. Cras and J. J. Steggerda, ibid. 7, 805 (1968). 
A scale of limiting ionic equivalent conductances in this solvent based indirectly on tetraisoamylammonium tetraisoamylborate as reference electrolyte is proposed by Coetzee and Cunningham ${ }^{4}$. Because these values were obtained by a conversion from their measurements in acetonitrile, we measured the single ion conductivities of several ions of some of the reported complexes in nitrobenzene and compared these with the parameters proposed.

\section{Results and Discussion}

The $\mathbf{C}-\mathbf{N}$ stretching frequencies for several of the newly prepared and related complexes are given in Table I. From these data it can be concluded that the perchlorate and the hexafluorophosphate ions also have

Table I

$\mathrm{C}-\mathrm{N}$ stretching frequencies $\left(\mathrm{cm}^{-1}\right)$ for $\mathrm{Au}\left(\boldsymbol{R}_{\mathbf{2}} \mathrm{dtc}\right) X$ complexes in the crystalline state and in chloroform solution.

\begin{tabular}{|c|c|c|c|c|c|c|c|c|}
\hline \multicolumn{3}{|c|}{$\mathrm{Au}\left(n-\mathrm{Bu}_{2} \mathrm{dtc}\right)_{2} X$} & \multicolumn{3}{|c|}{$\mathrm{Au}\left(R_{2} \mathrm{dtc}\right)_{2} \mathrm{Br}$} & \multicolumn{3}{|c|}{$\mathrm{Au}\left(R_{2} \mathrm{dtc}\right)_{2} \mathrm{AuBr} r_{2}$} \\
\hline$X^{-}$ & solid & soln. & $R$ & solid & soln. & $R$ & solid & soln. \\
\hline $\mathrm{Br}^{-}$ & 1575 & 1547 & $\mathbf{H}$ & $\left\{\begin{array}{l}1475 \\
1455\end{array}\right.$ & insol. & & & \\
\hline $\mathrm{ClO}_{4}^{-}$ & 1565 & 1548 & Mie & $\left\{\begin{array}{l}1600 \\
1550\end{array}\right.$ & 1580 & Me & 1565 & insol. \\
\hline $\mathrm{PF}_{6}^{-}$ & 1565 & 1548 & Et & 1550 & 1546 & $\mathrm{Et}$ & 1570 & 1546 \\
\hline $\mathrm{AuBr}_{4}^{-}$ & 1565 & 1545 & $n-\operatorname{Pr}$ & 1540 & 1545 & $n-\operatorname{Pr}$ & 1550 & 1542 \\
\hline $\mathrm{CuBr}_{2}^{-}$ & 1550 & 1543 & $n-\mathrm{Bu}$ & 1575 & 1547 & $n-\mathrm{Bu}$ & $1550^{a}$ & 1545 \\
\hline $\mathrm{AgBr}_{2}^{-}$ & 1550 & 1543 & $\mathbf{P h}$ & 1442 & 1430 & $\mathrm{Ph}$ & 1440 & 1430 \\
\hline $\mathrm{AuCl}_{2}^{-}$ & $1550^{\text {: }}$ & 1545 & & & & & & \\
\hline $\mathrm{AuBr}_{2}^{-}$ & $1550^{n}$ & 1545 & & & & & & \\
\hline $\mathrm{AuI}_{2}^{-}$ & $1550^{\mathrm{a}}$ & 1542 & & & & & & \\
\hline $\mathrm{Au}(\mathrm{mnt})_{2}{ }^{-}$ & 1550 & 1547 & & & & & & \\
\hline $\mathrm{Au}(\mathrm{tdt})_{2}^{-}$ & 1550 & 1541 & & & & & & \\
\hline
\end{tabular}

a Ref. 3

a distinct effect on the charge on the nitrogen, resulting in an increased value for the $\mathrm{C}-\mathrm{N}$ stretching frequency compared with the other complexes. Further information concerning this influence can be obtained from the resolution of the crystal structures of three other compounds $\mathrm{Au}\left(n-\mathrm{Bu}_{2} \mathrm{dtc}\right)_{2} \mathrm{CuBr}_{2}{ }^{5}, \quad \mathrm{Au}\left(n-\mathrm{Bu}_{2} \mathrm{dtc}\right)_{2} \mathrm{AgBr}_{2}{ }^{6}$, and $\mathrm{Au}\left(n-\mathrm{Bu}_{2} \mathrm{dtc}\right)_{2} \mathrm{Au}-$

${ }^{4}$ J.F. Coetzee and G. P. Cunningham, J. Am. Chem. Soc. 87, 2529 (1965).

${ }^{5}$ P. T. Beurskens, J. A. Cras, Th. W. Hummelink and J. G. M. van der Linden, Rec. Trav. Chim. 89, 984 (1970).

${ }^{6}$ J. A. Cras, J. H. Noordik, P. T. Beurskens, and A. M. Verhoeven, J. Crystal Mol. Structure, 1, 155 (1971). 
(mnt) ${ }_{2}{ }^{7}$. Since the $\mathrm{AgBr}_{2}{ }^{-}$ion is located close to the sulphur atoms of the dithiocarbamate this ion cannot influence the charge of the nitrogen. Moreover, in the $\mathrm{Au}\left(n-\mathrm{Bu}_{2} \mathrm{dtc}\right)_{2} \mathrm{Au}(\mathrm{mnt})_{2}$ compound the cations and the anions alternate in rows with a mutual distance of approximately $5 \AA$ and since the same value for the $\mathrm{C}-\mathrm{N}$ frequency is found $\left(1550 \mathrm{~cm}^{-1}\right)$ for all the complexes $\mathrm{Au}\left(n-\mathrm{Bu}_{2} \mathrm{dtc}\right)_{2} X$ with $X=\mathrm{CuBr}_{2}{ }^{-}, \mathrm{AgBr}_{2}{ }^{-}, \mathrm{AuCl}_{2}{ }^{-}$, $\mathrm{AuBr}_{2}{ }^{-}, \mathrm{AuI}_{2}{ }^{-}$and $\mathrm{Au}(\mathrm{mnt})_{2}{ }^{-}$, we conclude that there is no interaction between these anions and the nitrogen atom in the crystalline state.

For the ethyl and $n$-propyl dithiocarbamates there is, surprisingly, a reversed effect; the $\mathrm{C}-\mathrm{N}$ frequency for the $\mathrm{Br}^{-}$complexes is even lower compared with the $\mathrm{AuBr}_{2}{ }^{-}$compounds. The differences in frequencies for these anions may also be due to electrostatic effects in the crystalline state and therefore the $\mathrm{C}-\mathrm{N}$ frequencies for the $\mathrm{Au}\left(\mathrm{R}_{2} \mathrm{dtc}\right)_{2}{ }^{+}$compounds were measured in chloroform solutions (Table I). From the values obtained it can be concluded that these interactions are absent in solution. For the ethyl, $n$-propyl and $n$-butyl compounds a constant value is found $\left(1545 \mathrm{~cm}^{-1}\right)$. Such a less marked change in frequency ascending the homologous series is found also for the cupric $N, N$-di-alkyldithiocarbamates $^{8}\left[\mathrm{Cu}\left(R_{2} \mathrm{dtc}\right)_{2} ; R=\mathrm{Et}, n-\mathrm{Pr}, n-\mathrm{Bu}\right]$. When $R=\mathrm{H}$ and phenyl the $\mathrm{C}-\mathrm{N}$ frequency is found at lower energy in the solid state and in solution (Table I), as could be expected especially for an electron withdrawing group ${ }^{9}$. A comparison of the spectra recorded in chloroform and in the solid state shows no significant shifts for other absorption bands in the range $700-1700 \mathrm{~cm}^{-1}$.

Conductance study. The concentration-dependence of the equivalent conductivities $\left(\Lambda_{e}\right)$ is expressed by the Onsager limiting law $\Lambda_{e}=\Lambda_{0}$ $A \sqrt{C}$, where $C$ is the equivalent concentration. $\Lambda_{0}$ can be determined by plotting $\Lambda_{e}$ as a function of $\sqrt{C}$.

For several of the reported complexes $\Lambda_{e}$ was measured in nitrobenzene in the concentration range $10^{-3}-10^{-4}$ molar. $\Lambda_{0}$ and $A_{\text {exp }}$ were determined using the method of least squares (Table II). These values of $A$ can also be calculated assuming a 1:1 electrolyte to be present, using data for dielectric constant and viscosity given for nitrobenzene $\left(25.0^{\circ}\right)^{10}$ : $A_{\text {calc. }}=\alpha \Lambda_{0}+\beta=0.780 \Lambda_{0}+44.12$. These values of $A_{\text {calc. }}$ are in good agreement with those observed $\left(A_{\text {exp. }}\right)$.

The observed limiting conductivities are also comparable with the data given for $n-\mathrm{Bu}_{4} \mathrm{NB}(\mathrm{Ph})_{4}{ }^{11}$ and for $n-\mathrm{Bu}_{4} \mathrm{NBF}(\mathrm{Ph})_{3}{ }^{10}$.

${ }^{7}$ J. H. Noordik and P. T. Beurskens, to be published. We thank Drs. Noordik and Dr.

Beurskens for communication prior to publication.

8 J. Chatt, L. A. Duncanson and L. M. Venanzi, Suomen Kemi 29B, 75 (1956).

${ }^{9}$ D. Coucouvanis, Progr. Inorg. Chem. 11, 233 (1970).

10 R. M. Fuoss and E. Hirsch, J. Am. Chem. Soc. 82, 1013 (1960).

11 E. G. Taylor and C. A. Kraus, ibid. 69.1731 (1947). 
Table II

Electric conductivities in nitrobenzene $\left(25.0^{\circ}\right)$

\begin{tabular}{lccc}
\hline \multicolumn{1}{c}{ Complex } & $\begin{array}{c}\Lambda_{0} \\
\left(\mathrm{~cm}^{2} \mathrm{ohm}^{-1} \text { mole }^{-1}\right)\end{array}$ & $A_{\text {exp. }}$ & $A_{\text {calc. }}$ \\
\hline $\mathrm{Au}\left(n-\mathrm{Bu}_{2} \mathrm{dtc}\right)_{2} \mathrm{Br}$ & 30.96 & 83.7 & 68.3 \\
$\mathrm{Au}\left(n-\mathrm{Bu}_{2} \mathrm{dtc}\right)_{2} \mathrm{ClO}_{4}$ & 30.51 & 74.9 & 67.9 \\
$\mathrm{Au}\left(n-\mathrm{Bu}_{2} \mathrm{dtc}\right)_{2} \mathrm{AuBr}_{2}$ & 30.08 & 66.5 & 67.6 \\
$\mathrm{Au}\left(n-\mathrm{Bu}_{2} \mathrm{dtc}\right)_{2} \mathrm{PF}_{6}$ & 29.54 & 64.5 & 67.2 \\
$\mathrm{Au}\left(n-\mathrm{Bu}_{2} \mathrm{dtc}\right)_{2} \mathrm{AuI}{ }_{2}$ & 28.87 & 77.1 & 66.6 \\
$\mathrm{Au}\left(n-\mathrm{Bu}{ }_{2} \mathrm{dtc}\right)_{2} \mathrm{AuBr}{ }_{4}$ & 26.95 & 82.7 & 65.1 \\
$(n-\mathrm{Bu})_{4} \mathrm{NAu}(\mathrm{tdt})_{2}$ & 24.16 & 79.2 & 63.0 \\
$\mathrm{Au}\left(n-\mathrm{Bu}{ }_{2} \mathrm{dtc}\right)_{2} \mathrm{Au}(\mathrm{tdt})_{2}$ & 21.67 & 79.9 & 61.0 \\
$\mathrm{Au}\left(n-\mathrm{Bu}{ }_{2} \mathrm{dtc}\right)_{2} \mathrm{~B}(\mathrm{Ph})_{4}$ & 19.86 & 66.3 & 59.6 \\
$(n-\mathrm{Bu})_{4} \mathrm{NClO}{ }_{4}$ & 31.84 & 84.5 & 68.9 \\
$(n-\mathrm{Bu})_{4} \mathrm{NB}(\mathrm{Ph})_{4}$ & 22.37 & 59.4 & 61.6 \\
$(n-\mathrm{Bu})_{4} \mathrm{NB}(\mathrm{Ph})_{4}{ }^{\mathrm{a}}$ & 22.18 & 53.1 & 61.4 \\
$(n-\mathrm{Bu})_{4} \mathrm{NBF}\left(\mathrm{Ph}{ }^{\mathrm{N}}{ }^{\mathrm{N}}\right.$ & 23.78 & 60.8 & \\
\hline
\end{tabular}

"Ref 11 .

b Ref. 10.

With the single ion conductivities given ${ }^{4}$ for the $\mathrm{Br}^{-}$ion (21.9) and the $\mathrm{B}(\mathrm{Ph})_{4}{ }^{-}$ion (10.8) and with the measured values of $\Lambda_{0}$, the single ion conductivity for the $\mathrm{Au}\left(n-\mathrm{Bu}_{2} \mathrm{dtc}\right)_{2}{ }^{+}$ion was determined: $\lambda_{0}{ }^{+}=9.1$. With this value for $\mathrm{Au}\left(n-\mathrm{Bu}_{2} \mathrm{dtc}\right)_{2}{ }^{+}$single ion conductivities for several negative ions could be derived (Table III).

Table III

Single ion conductivities $\left(\lambda_{0}\right)$ in nitrobenzene (25.0 $0^{\circ}$ based upon

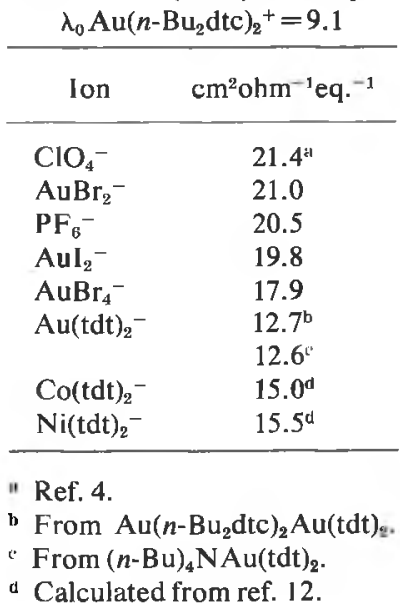


The single ion conductivities given by Coetzee and Cunningham ${ }^{4}$ in acetonitrile and nitrobenzene show the following relationship (Table IV):

$$
\frac{\lambda_{0} \text { in acetonitrile }}{\lambda_{0} \text { in nitrobenzene }}=5.35
$$

Using this ratio the single ion conductivities for $\mathrm{Ni(tdt})_{2}{ }^{-}$and $\mathrm{Co}(\mathrm{tdt})_{2}{ }^{-}$in nitrobenzene could be calculated from the conductance data in acetonitrile ${ }^{12}$ giving 15.5 and 15.0 , respectively, comparable with the measured value for $\mathrm{Au}(\mathrm{tdt})_{2}{ }^{-}(12.6)$.

\section{Table IV}

Single ion conductivities in nitrobenzene and in acetonitrile $\left(\mathrm{cm}^{2} \mathrm{ohm}^{-1}\right.$ eq. $\left.{ }^{-1}\right)$.

\begin{tabular}{lrcc}
\hline \multicolumn{1}{c}{ Ion } & acetonitrile & nitrobenzene & \multicolumn{1}{c}{$\lambda_{0}$ acetonitrile } \\
& & & $\lambda_{0}$ nitrobenzene \\
\hline $\mathrm{Me}_{4} \mathrm{~N}^{+}$ & 94.55 & 17.0 & 5.56 \\
$\mathrm{Et}_{4} \mathrm{~N}^{+}$ & 85.05 & 16.1 & 5.34 \\
$(n-\mathrm{Pr})_{4} \mathrm{~N}^{+}$ & 70.65 & 13.2 & 5.35 \\
$(n-\mathrm{Bu})_{4} \mathrm{~N}^{+}$ & 61.93 & 11.55 & 5.36 \\
$(i-\mathrm{Am})_{4} \mathrm{~N}^{+}$ & 57.24 & 10.70 & 5.35 \\
$(i-\mathrm{Am})_{4} \mathrm{~B}^{-}$ & 57.24 & 10.70 & 5.35 \\
$(\mathrm{Ph})_{4} \mathrm{~B}^{-}$ & 57.72 & 10.79 & 5.35 \\
$\mathrm{Br}^{-}$ & 100.05 & 21.93 & 4.56 \\
$\mathrm{I}^{-}$ & 100.03 & 21.25 & 4.80 \\
\hline
\end{tabular}

\section{Experimental}

Materials. $\mathrm{Au}\left(n-\mathrm{Bu}_{2} \mathrm{dtc}\right)_{2} \mathrm{Br}^{2}, \mathrm{Au}\left(n-\mathrm{Bu}_{2} \mathrm{dtc}\right)_{2} \mathrm{AuBr}_{4}{ }^{1}, \mathrm{Au}\left(n-\mathrm{Bu}_{2} \mathrm{dtc}\right)_{2} \mathrm{AuBr}_{2}{ }^{3}, \mathrm{Au}\left(n-\mathrm{Bu}_{2}-\right.$ $\mathrm{dtc})_{2} \mathrm{AuI}_{2}{ }^{3}, \mathrm{Au}\left(n-\mathrm{Bu}_{2} \mathrm{dtc}\right)_{2} \mathrm{CuBr}_{2}{ }^{5}, n-\mathrm{Bu}_{4} \mathrm{NAu}(\mathrm{tdt})_{2}{ }^{12}, n-\mathrm{Bu}_{4} \mathrm{NAu}(\mathrm{mnt})_{2}{ }^{13}, \mathrm{Na}_{2} \mathrm{mnt}^{14}, n-\mathrm{Bu}_{4^{-}}$ $\mathrm{ClO}_{4}{ }^{15}, n-\mathrm{Bu}_{4} \mathrm{NBPh}_{4}{ }^{16}$, were prepared as described.

Toluene-3,4-dithiol was obtained commercially (Merck, Darmstadt). AgBr was prepared from aqueous solutions of silver nitrate and sodium bromide and was used immediately after several washings with distilled water and acetonitrile.

$N, N . N^{\prime}, N^{\prime}$-Tetra-alkylthiuram disulfides were prepared as described by $\hat{A} k e r s t r o ̈ m^{17}$.

Analyses. Metals were analyzed by atomic absorption spectrophotometric methods.

12 A. Davison, D. V. Howe and E. T. Shawl, Inorg. Chem. 6, 458 (1967).

13 A. Davison, N. Edelstein, R. H. Holm and A. H. Maki, ibid. 2, 1227 (1963).

${ }^{14}$ J. Locke and J. A. McCleverty, ibid. 5, 1157 (1966).

15 I. M. Kolthoff and J. F. Coetzee, J. Am. Chem. Soc. 89, 6859 (1967).

16 a. F. Accascina, S. Petrucci and R. M. Fuoss, ibid., 81, 1301 (1959);

b. W. Miller and D.W.Watts, ibid.89, 6859 (1967).

17 S. Akerström, Arkiv Kemi 14, 387 (1959). 
The other elemental analyses were carried out in the Micro-analytical Department of this University. All melting points are uncorrected.

\section{Preparations.}

$A u\left(\mathbf{n}-B u_{2} d t c\right)_{2} P F_{6} .10 \mathrm{~g}$ of anion exchange resin (Amberlite IR A 400) were converted to the $\mathrm{PF}_{6}$ - form by passing a solution of $5 \mathrm{~g} n-\mathrm{Bu}_{4} \mathrm{NPF}_{6}$ in water through the exchange column. Water was removed with ethanol and the ethanol with dimethyl sulfoxide (DMSO). A solution of $1.1 \mathrm{~g}$ of $\mathrm{Au}\left(n \mathrm{Bu}_{2} \mathrm{dtc}\right)_{2} \mathrm{AuBr}_{2}$ in DMSO was passed through the column and the resin was washed with DMSO. The solution and washings were collected and the solvent was removed in vacuo. After several crystallizations from acetonitrile and carbon tetrachloride solutions, $0.35 \mathrm{~g}$ of yellow crystals was obtained, m.p. 156.8-157.5 .

Found

: C, 28.9; H, 4.8: N, 3.6; S, 17.4: Au, 26.2.

Calcd. for $\mathrm{C}_{18} \mathrm{H}_{36} \mathrm{AuF}_{8} \mathrm{~N}_{2} \mathrm{PS}_{4}(\mathrm{M}=750.7)$ : $\mathrm{C}, 28.80 ; \mathrm{H}, 4.80 ; \mathrm{N}, 3.73 ; \mathrm{S}, 17.08$;

$\mathrm{Au}, 26.24$.

$\mathrm{Au}\left(\mathbf{n}-\mathrm{Bu}_{2} d t \mathrm{c}\right)_{2} \mathrm{ClO}_{4}$ was prepared following the procedure described for the $\mathrm{PF}_{6}{ }^{-}-$ complex, except that sodium perchlorate was used and nitrobenzene was taken as solvent. Recrystallizations from mixtures of chloroform and diethyl ether gave yellow crystals, m.p. $138.0-138.5^{\circ}$.

Found

: N, 3.8; S, 18.0; Au, 28.7.

Calcd. for $\mathrm{C}_{18} \mathrm{H}_{36} \mathrm{AuCIN} \mathrm{O}_{2} \mathrm{O}_{4} \mathrm{~S}_{4}(\mathrm{M}=705.2)$ : N, 3.79; S, 18.19; $\mathrm{Au}, 27.93$.

$A u\left(\mathbf{n}-B u_{2} d t c\right)_{2} B(P h)_{4}$. This complex was prepared by adding an equimolar amount of $\mathrm{NaB}(\mathrm{Ph})_{4}$ in $5 \mathrm{ml}$ of ethanol to $0.68 \mathrm{~g}$ of $\mathrm{Au}\left(n-\mathrm{Bu}_{2} \mathrm{dtc}\right)_{2} \mathrm{Br}$ in $15 \mathrm{ml}$ of methylene chloride. The resulting solution was filtered and the solvent evaporated in vacuo. The residue was dissolved in methylene chloride. To this solution diethyl ether was slowly added giving $0.8 \mathrm{~g}$ of orange red needles, m.p. $160-161^{\circ}$.

Found : C, 54.7; H, 6.6; Au, 21.2 .

Calcd. for $\mathrm{C}_{42} \mathrm{H}_{56} \mathrm{AuBN}_{2} \mathrm{~S}_{4}(\mathrm{M}=924.96)$ : C, 54.54; H, 6.10; $\mathrm{Au}, 21.29$.

$A u\left(\mathbf{n}-B u_{2} d t c\right)_{2} A u(t d t)_{2}$. This compound was prepared by adding to a solution of $0.68 \mathrm{~g}$ of $\mathrm{Au}\left(n-\mathrm{Bu}_{2} \mathrm{dtc}\right)_{2} \mathrm{Br}$ in methylene chloride an equimolar amount $(0.75 \mathrm{~g})$ of $n-\mathrm{Bu}_{4} \mathrm{NAu}(\mathrm{tdt})_{2}$ in $15 \mathrm{ml}$ of methylene chloride at $0^{\circ}$. To promote crystallization $200 \mathrm{ml}$ of methanol were added. The dark green product was filtered and washed with methanol and diethyl ether.

Recrystallization from acetone or methylene chloride/diethyl ether mixtures gave a green product in $90 \%$ yield, $\mathrm{m}$ p. $134-135^{\circ}$.

Found

: C, 33.4; $\mathrm{H}, 4.3 ; \mathrm{N}, 2.4$.

Calcd. for $\mathrm{C}_{16} \mathrm{H}_{24} \mathrm{AuNS}_{4}(\mathrm{M}=1111.2)$ : $\mathrm{C}, 34.59 ; \mathrm{H}, 4.35 ; \mathrm{N}, 2.52$.

$A u\left(\mathbf{n}-B u_{2} d t c\right)_{2} A u(m n t)_{2}$. This complex was prepared similarly to the procedure given for $n-\mathrm{Bu}_{4} \mathrm{NAu}(\mathrm{mnt})_{2}{ }^{13}$, only an equivalent amount of $\mathrm{Au}\left(n-\mathrm{Bu}_{2} \mathrm{dtc}\right)_{2} \mathrm{Br}$ in $5 \mathrm{ml}$ of ethanol was added to precipitate the $\mathrm{Au}(\mathrm{mnt})_{2}{ }^{-}$ion. The precipitate was filtered and recrystallized from acetone giving brown yellow needles, m.p. $169-170^{\circ}$.

Found

: C, 28.9; H, 3.3; N, 8.1; S, 23.3; Au, 36.0.

Calcd. for $\left(\mathrm{C}_{13} \mathrm{H}_{18} \mathrm{AuN}_{3} \mathrm{~S}_{4}\right)_{2}(\mathrm{M}=1083.1)$ : $\mathrm{C}, 28.83 ; \mathrm{H}, 3.35 ; \mathrm{N}, 7.76 ; \mathrm{S}, 23.68$;

Au, 36.38. 
$A u\left(\mathrm{n}-B u_{2} d t c\right)_{2} A g B r_{2}$. To a solution of $2.0 \mathrm{~g}$ of $\mathrm{Au}\left(n-\mathrm{Bu} \mathrm{u}_{2} \mathrm{dtc}\right)_{2} \mathrm{Br}$ in $200 \mathrm{ml}$ of acetonitrile an excess of freshly prepared $\mathrm{AgBr}(0.9 \mathrm{~g})$ was added. The mixture was stirred at $45^{\circ}$ for several hours. The solution was filtered and the solvent evaporated slowly. Orange needles were obtained in $50 \%$ yield, m.p. $168.5-170.0^{\circ}$.

Found : C, 24.8; H, 4:3; N, 3.2; S, 14.8; Au,

23.0; $\mathrm{Br}, 17.4$

Calcd. for $\mathrm{C}_{18} \mathrm{H}_{36} \mathrm{AgAuBr} \mathrm{N}_{2} \mathrm{~S}_{4}(\mathrm{M}=873.4) ; \mathrm{C}, 24.75 ; \mathrm{H}, 4.15 ; \mathrm{N}, 3.21 ; \mathrm{S}, 14.68$; $\mathrm{Au}, 22.55 ; \mathrm{Br} .18 .30$.

$A u\left(\mathbf{R}_{2} d t c\right)_{2} B r$ with $R=\mathrm{H}, \mathrm{Me}, \mathrm{Et}, n-\mathrm{Pr}$, and phenyl were prepared as described for the analogous $n$-butyl compound ${ }^{2}$. An equivalent amount of the appropriate thiuram disulfide (dissolved in chloroform or methanol) was added to aqueous $\mathrm{AuBr}_{2}{ }^{-}$-containing solutions.

$\mathrm{Au}\left(\mathrm{H}_{2} \mathrm{dtc}\right)_{2} \mathrm{Br}, \mathrm{m.p} .>360^{\circ}$; anal. found: C, 5.5; H, 0.87; N, 5.8; Au, 42.7 .

Calcd. for $\mathrm{C}_{2} \mathrm{H}_{4} \mathrm{AuBrN}_{2} \mathrm{~S}_{4}(\mathrm{M}=461.2)$ : C, $5.21 ; \mathrm{H}, 0.87 ; \mathrm{N}, 6.07 ; \mathrm{Au}, 42.71$.

$\mathrm{Au}\left(\mathrm{Me}_{2} \mathrm{dtc}\right)_{2} \mathrm{Br}, \mathrm{m} . \mathrm{p} .248^{\circ}$ dec.: anal. found: $\mathrm{C}, 14.0 ; \mathrm{H} .2 .3 ; \mathrm{N}, 5.3 ; \mathrm{Au} .37 .5$.

Calc. for $\mathrm{C}_{8} \mathrm{H}_{12} \mathrm{AuBrN}_{\mathrm{z}} \mathrm{S}_{4}(\mathrm{M}=517.3)$ : $\mathrm{C}, 13.93 ; \mathrm{H}, 2.34 ; \mathrm{N}, 5.41 ; \mathrm{Au}, 38.08$.

$\mathrm{Au}\left(\mathrm{Et}_{2} \mathrm{dtc}\right)_{2} \mathrm{Br}$. m.p. $186^{\circ}$; anal. found: $\mathrm{C}, 21.0 ; \mathrm{H}, 3.4 ; \mathrm{N}, 5.0 ; \mathrm{S}, 22.2 ; \mathrm{Au}, 34.2$.

Calc. for $\mathrm{C}_{10} \mathrm{H}_{20} \mathrm{AuBrN}_{2} \mathrm{~S}_{4}(\mathrm{M}=573.4)$ : C, 20.95; H, 3.52; N. 4.89; S, 22.37: $\mathrm{Au}, 34.33$.

$\mathrm{Au}\left(n-\mathrm{Pr}_{2} \mathrm{dtc}\right)_{2} \mathrm{Br}$, m.p. $157^{\circ}$; anal. found: $\mathrm{C}, 26.7 ; \mathrm{H}, 4.5 ; \mathrm{N}, 4.6 ; \mathrm{S}, 20.3 ; \mathrm{Au}, 32.8$.

Calc. for $\mathrm{C}_{14} \mathrm{H}_{2 \mathrm{~B}} \mathrm{AuBrN} \mathrm{S}_{4}(\mathrm{M}=629.5)$ : C, 26.71; $\mathrm{H}, 4.48 ; \mathrm{N}, 4.45 ; \mathrm{S}, 20.37 ; \mathrm{Atr}, 31.29$.

$\mathrm{Au}\left(\mathrm{Ph}_{2} \mathrm{dtc}\right)_{2} \mathrm{Br}$, m.p. $264^{\circ}$; anal. found: $\mathrm{C}, 40.4 ; \mathrm{H}, 2.7 ; \mathrm{N}, 3.7 ; \mathrm{Au}, 25.5$.

Calc. for $\mathrm{C}_{26} \mathrm{H}_{20} \mathrm{AuBrN} \mathrm{S}_{2} \mathrm{~S}_{4}(\mathrm{M}=765.6)$ : C, 40.79; $\mathrm{H}, 2.63 ; \mathrm{N}, 3.66 ; \mathrm{Au}, 25.73$.

$\mathrm{Au}\left(R_{2} \mathrm{dtc}\right)_{2} \mathrm{AuBr}_{2}$ with $R=\mathrm{Me}, \mathrm{Et}, n-\mathrm{Pr}$, and phenyl were prepared by the procedure described above for the bromide complexes. Only half an equivalent amount of the corresponding thiuram disulfide was used.

$\mathrm{Au}\left(\mathrm{Me}_{2} \mathrm{dtc}\right)_{2} \mathrm{AuBr}_{2}$, m.p. $266^{\circ}$ dec.; anal. found: C, 9.1; $\mathrm{H}, 1.6 ; \mathrm{N}, 3.4 ; \mathrm{S}, 16.0 ; \mathrm{Au}, 51.2$, Calc. for $\mathrm{C}_{6} \mathrm{H}_{12} \mathrm{Au}_{2} \mathrm{Br}_{2} \mathrm{~N}_{2} \mathrm{~S}_{4}(\mathrm{M}=794.1)$ : C, 9.08; $\mathrm{H}, 1.52 ; \mathrm{N}, 3.53 ; \mathrm{S}, 16.15 ; \mathrm{Au}, 49.60$. $\mathrm{Au}\left(\mathrm{Et}_{2} \mathrm{dtc}\right)_{2} \mathrm{AuBr}_{2}$, m.p. $149^{\circ}$;.anal. found: $\mathrm{C}, 14.2 ; \mathrm{H}, 2.4 ; \mathrm{N}, 3.2 ; \mathrm{Au}, 46.2$.

Calc. for $\mathrm{C}_{10} \mathrm{H}_{20} \mathrm{Au}_{2} \mathrm{Br}_{2} \mathrm{~N}_{2} \mathrm{~S}_{4}(\mathrm{M}=850.3)$ : C, $14.13 ; \mathrm{H}, 2.37 ; \mathrm{N}, 3.29 ; \mathrm{Au}, 46.33$.

$\mathrm{Au}\left(n-\mathrm{Pr}_{2} \mathrm{dtc}\right)_{2} \mathrm{AuBr}_{2}$, m.p. $120^{\circ}$; anal. found: C, 18.6; H, 3.1; N, 3.0; S, 14.2; Au, 43.5 .

Calc. for $\mathrm{C}_{14} \mathrm{H}_{28} \mathrm{Au}_{2} \mathrm{Br}_{2} \mathrm{~N}_{2} \mathrm{~S}_{4}(\mathrm{M}=906.4)$ : C, 18.55; $\mathrm{H}, 3.11 ; \mathrm{N}, 3.09 ; \mathrm{S}, 14.15 ; \mathrm{Au}, 43.46$.

$\mathrm{Au}\left(\mathrm{Ph}_{2} \mathrm{dtc}\right)_{2} \mathrm{AuBr}_{2}$, m.p. $268^{\circ}$; anal. found: C, $29.9 ; \mathrm{H}, 2.0 ; \mathrm{N}, 2.6 ; \mathrm{S}, 12.3 ; \mathrm{Au}, 37.4$.

Calc. for $\mathrm{C}_{26} \mathrm{H}_{20} \mathrm{Au}_{2} \mathrm{Br}_{2} \mathrm{~N}_{2} \mathrm{~S}_{4}(\mathrm{M}=1042.5)$ : C. 29.96; $\mathrm{H}, 1.93 ; \mathrm{N}, 2.69 ; \mathrm{S}, 12.30 ; \mathrm{Au}$. 37.79 .

\section{Physical measurements}

Infrared spectra were recorded with a Perkin Elmer 157 or a Hitachi EP1-G3 spectrophotometer, using the $\mathrm{KBr}$ disc technique, checked against Nujoll mulls. Electric conductivities in nitrobenzene were measured as described previously ${ }^{3}$.

\section{Acknowledgement}

The author wishes to thank Professor J. J. Steggerda for critically reading the manuscript, Mr. $P$. $J$. Koonen for experimental assistance and Mr.J. Diersmann for performing the micro-analyses. 